\title{
Water quality assessment along the segments of Bagmati River in Kathmandu valley, Nepal
}

\author{
Binod Baniya ${ }^{1,2,3}$, Nitesh Khadka ${ }^{3,4^{*}}$ Shravan Kumar Ghimire ${ }^{3,4}$, Hom Baniya ${ }^{5}$, Shankar \\ Sharma $^{3,6}$, Yam Prasad Dhital ${ }^{7}$, Ranjana Bhatta ${ }^{2}$ and Bishnu Bhattarai ${ }^{8}$ \\ ${ }^{1}$ Land Surface Processes and Global Change Research Group, Institute of Geographical Sciences and Natural Resources \\ Research, Chinese Academy of Sciences, Beijing, China \\ 2 Department of Environmental Science, Patan Multiple Campus, Tribhuvan University, Nepal \\ ${ }^{3}$ University of Chinese Academy of Sciences, Beijing 100049, China \\ ${ }^{4}$ Institute of Mountain Hazards and Environment, Chinese Academy of Sciences, Chengdu 610041, China \\ ${ }^{5}$ Department of Physics, Tri-Chandra College, Tribhuvan University, Kathmandu, Nepal \\ ${ }^{6}$ National Tibetan Plateau Data Center, Institute of Tibetan Plateau Research, Chinese Academy of Sciences, Beijing, 100101, China \\ ${ }^{7}$ Institute of Eco-Chongming, Faculty of Earth Sciences, East China Normal University, Shanghai, China \\ ${ }^{8}$ Himalayan College of Agricultural Sciences and Technology, Balkhu, Kathmandu, Nepal
}

\begin{abstract}
Identification of pollution in the river helps to know the state of the river ecosystem. The study aimed to assess the water quality of the Bagmati River by analyzing the physical and chemical condition and comparing it with national and international standards. The water samples were taken from 10 different sampling sites along the length of the Bagmati River inside Kathmandu Valley, i.e., from Sundarijal to Saibubhanjyang. A total of 30 physical and chemical parameters were examined. The results showed that the $\mathrm{pH}$ ranges from 6.0 to 7.5 in different sampling locations. The highest dissolved oxygen (DO) (8.5 mg/L) was found at the upstream while the lowest, i.e., $3.4 \mathrm{mg} / \mathrm{L}$ and $3.5 \mathrm{mg} / \mathrm{L}$, was found at the urban core of the valley, i.e., Teku and Thapathali, respectively. The BOD, COD, oil, and grease considerably exceeded the $\mathrm{WHO}$ and national generic effluent standard. Most of the heavy metals in the river water were below the range of standard. The concentrations of all pesticides were found below $10 \mu \mathrm{g} / \mathrm{L}$ except heptachlor exoepoxide. The highest concentration of heptachlor exoepoxide $(75 \mu \mathrm{g} / \mathrm{L})$ was found at Balkhu, followed by Thapathali $(69 \mu \mathrm{g} / \mathrm{L})$ and Teku $(62 \mu \mathrm{g} / \mathrm{L})$. The result showed that the middle-urbanized segment, i.e., from Gokarna to Teku, is heavily polluted than the upstream and downstream segments of the river. The results are of great significance for policy formulation and implementation of the ecosystem restoration project of Bagmati River in the Kathmandu valley, Nepal.
\end{abstract}

Keywords: Bagmati River, Kathmandu valley, Nepal, Water pollution

\section{Introduction}

Healthy river ecosystems maintain the structural integrity of their physical, chemical, and biological environment. Meanwhile, they provide ecosystem services through ecological processes and ecosystem function (Shrestha et al., 2019). Nepal is one of the richest countries in the world in the water system (WECS, 2011). Among several river systems in Nepal, the Bagmati River is the principal river in central Nepal, which originates from the Shivapuri range in the north of Kathmandu. The river is fed by springs and monsoon rainfall and drains across the Mahabharat Range to the Gangetic plain (GoN/NTNC, 2009). The Bagmati River basin can be divided into the upper basin, middle basin, and lower basin. The river in the Kathmandu Valley (the upper basin) stretches for $51 \mathrm{~km}$ with a catchment area of $678 \mathrm{~km}^{2}$ (Shrestha \& Tamrakar, 2012). The Bagmati River System not only has immense cultural and economic value for the people of Nepal, but it is also essential for the small-scale hydroelectricity, irrigation, and drinking water source. The river provides most of the city's drinking water from its upstream sources.
About $82 \%$ of the water volume is extracted daily from the surface water sources for drinking water supply in the Kathmandu Valley (Dahal et al., 2011). However, the water quality of the river is becoming a challenge because of severe pollution, especially in the downstream regions. Water quality refers to the set of concentrations, speciation, and physical partitions of inorganic and organic substances, including the composition and state of aquatic biota in the water body (APHA, 1998). Thousands of people suffer and die from water and sanitation-related diseases in the world (WHO, 2008). The water is still pristine in the upstream segment, but water qualities deteriorate with the start of the urban area and get heavily polluted across the city core of Kathmandu (ICIMOD, 2007; Pradhan, 1998). The overall water quality is sometimes difficult to evaluate from the limited number of samples and parameters (Chapman, 1992). The primary cause of the river quality deterioration is domestic and industrial effluents, solid waste disposal, washing, bathing, and substrate abstraction (Shrestha et al., 2008).

* Corresponding author: nkhadka@imde.ac.cn 
Kathmandu Metropolitan City, the only million-plus city in the country, has $9.72 \%$ of the national urban population (CBS, 2011). Rapid population growth, expansion of the urban areas, decreased agricultural and forest lands are responsible for the degradation of the Bagmati River (NUDS, 2015). Kathmandu city began to witness a population influx during the $1950 \mathrm{~s}$, and the rate increased exponentially after the 1980s (NWCF/NTNC, 2009). Normalized difference vegetation index has also shown risen urbanization in the Kathmandu Valley (Baniya et al., 2018). With the expansion of settlements, the volume of waste entering the river has increased. In 2012, the average municipal solid waste generation was $0.317 \mathrm{~kg}$ per capita per day, which is 1,435 tons per day or 524,000 tons per year of municipal solid waste generation in Nepal (ADB, 2013). The current water supply is remarkably lower than the demand in the Kathmandu Valley. In Kathmandu Valley, the water demand is 415.5 million liters per day (MLD) in 2016 and is expected to reach about 482 MLD by 2021. At the same time, KUKL's water supply is 366 MLD in 2016 and expected to increase 481.5 MLD in 2021 (Udmale et al., 2016). People heavily rely on private vendors, deep boring as well as alternative sources (e.g., well water, rainwater harvesting) which supply 50 MLD (MoUD, 2013). The rapid and unplanned expansion of Kathmandu city has left the river biologically dead. The river enters the valley near Sundarijal, after which the water quality starts to deteriorate (ADB , 2013). The river has been used as a dumping site for wastewater (domestic and industrial) and solid waste. Besides waste disposal, the river has been widely used for sand extraction and land encroachment (MoUD, 2015). The squatter settlements at the bank of the river add the organic load and pollutants to the river. During the last three decades, the discharge of Bagmati River has been observed to be decreasing except for pre-monsoon season (Dhital et al., 2013). The impacts of water quality deterioration have negative consequences on the aquatic eco-system, health, cultural, and aesthetic values.

Previous studies showed that water quality has deteriorated in the Bagmati River, mainly in the urbanized areas (Mishra et al., 2017; Paudyal et al., 2016). The concentration of the major ions and trace metals are reported in the urbanized section of the Bagmati River (Bhatt et al., 2013). A very few studies deal with the water chemistry of the Bagmati drainage network within Kathmandu Valley (Bhatt \& Gardner, 2009; Dhital et al., 2013; DHM, 1996, 2008; ENPHO, 1997; ITECO, 2003; Kannel et al., 2007; Karna \& Harada, 2001; Mishra et al., 2017; Paudyal et al., 2016). However, these studies have used limited parameters and focused only on nutrients, major ions, and trace metals. The results of water quality analysis revealed that the Bagmati River's water within the Kathmandu Valley is not suitable for drinking, recreation, and irrigation purposes (Stanley, 1994), which has been more deteriorated in the present condition. The length of sewerage in Kathmandu Metropolitan City is $1320 \mathrm{~km}$, where the urban population per kilometer sewerage service is 763 (MoLD, 2011). The poor management of drainage networks and direct discharge of sewage into the water sources are the primary cause of Bagmati water pollution. The estimated Biological Oxygen
Demand (BOD) in the Kathmandu Valley from industries and people is about 42 tons/day (Paudel, 1998). In most parts of the river, BOD is more than $15 \mathrm{mg} / \mathrm{L}$ (Mishra et al., 2017). In the dry season, the Bagmati River drains only $40 \%$ of the daily BOD generation, and the remaining is retained in the valley itself which is a major source of land and ground water pollution. The assessment of physical and chemical status of the river provides recent updates and basis for framing the appropriate pollution control measures. This study is intended to assess the water quality of the Bagmati River based on physical and chemical parameters by point sampling from its source to the end below $1.5 \mathrm{~km}$ down from Chovar in different length interval. In addition, the physical and chemical environmental parameters of Bagmati River are compared with the national and WHO standard.

\section{Materials and Methods}

This study has been conducted using laboratory experiments. The physical, chemical and pesticide characteristics were investigated during the pre-monsoon season in 10 different sites from upstream of the river (source of the river) to the downstream (lower end) of the Kathmandu city. Water samples were collected in sterilized plastic bottles with an airtight cap. During the sampling, air bubbles were avoided entirely from entering the sampling bottles. The samples were safely transported to the laboratory. The $\mathrm{pH}$ and Total Suspended Solid (TSS) were measured in the field.

\section{Study area}

The study area, Kathmandu Valley, is in the hilly region of Nepal at the geographical location of $27^{\circ} 32^{\prime} 13^{\prime \prime}$ to $27^{\circ} 49^{\prime}$ $10^{\prime \prime} \mathrm{N}$ and $85^{\circ} 11^{\prime} 31^{\prime \prime}$ to $85^{\circ} 31^{\prime} 38^{\prime \prime} \mathrm{E}$ with three administrative districts (Kathmandu, Bhaktapur, and Lalitpur). The Bagmati River originates from the north of Kathmandu, flows across the valley draining from the Lalitpur district on the south (Fig. 1). The water sampling was conducted from Sundarijal to Saibubhanjyang in the premonsoon season. The sampling sites were selected based on land use and river morphology of the Bagmati River. The ten sampling points along the river are Sundarijal, Gokarna, Tilganga, Gairigaun, Shankhamul-Dobhan, Thapathali, Pachalighat (Teku), Balkhu, Chobhar, and Saibu-bhanjyang (Fig. 1).

The river stretch of the study area was divided into upstream (Sundarijal and Gokarna), mid-stream (Tilganga, Gairigaun, Shankhamul-Dobhan, Thapathali, Pachalighat, and Balkhu), and downstream (Chobhar and Saibu-bhanjyang) of the Bagmati River within the Kathmandu Valley. Sundarijal and Gokarna are located at forest areas in the headstream of the river where the urban influences are minimal. Tilganga, Gairigaun, Shankhamul-Dobhan, Thapathali, Pachalighat, and Balkhu sampling sites are located at the mid-stretch, i.e., downtown (urban) core of the Kathmandu city. The remaining Chobhar and Saibu-bhanjyang are in the suburban areas with sparse settlements and agricultural lands downstream of the river. 


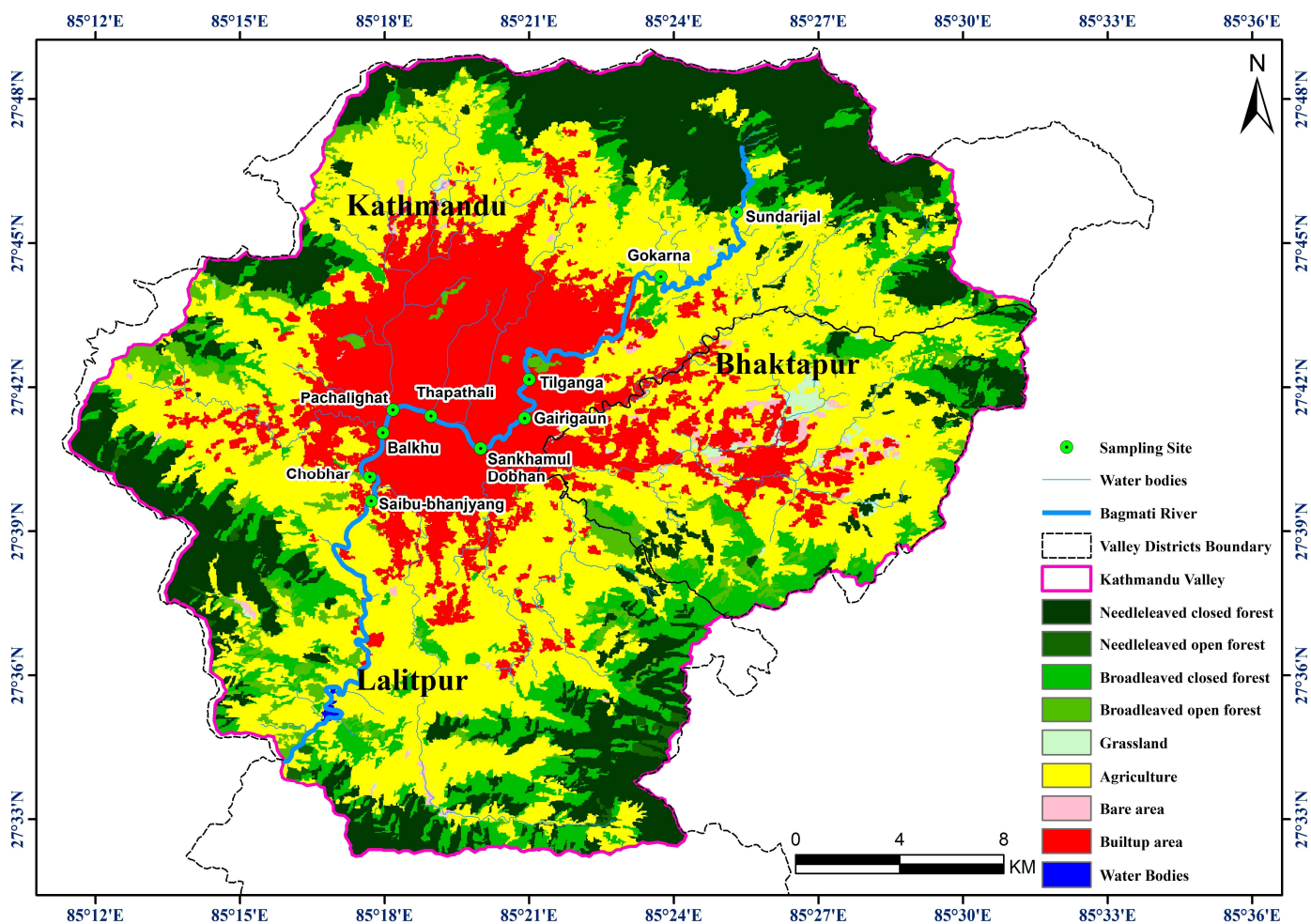

Figure 1 Land use and land cover of the Kathmandu valley (Uddin et al., 2015) and the location of 10 sampling points in the Bagmati River

\section{Methods and data analysis}

Thirty different water quality parameters (Table 1) were measured by using the standard method (APHA, 1998). The five days incubation at $20{ }^{\circ} \mathrm{C}$ for BOD, Potassium dichromate oxidation (open reflux, titrimetric) was used for Chemical Oxygen Demand (COD), heavy metals were determined by Atomic Absorber Spectrometer (AAS) method. Pesticides were measured by using Gas Chromatography and Mass Spectrophotometer following the standard guideline of the American Public Health Association (APHA) handbook (APHA, 1998). The parameters such as $\mathrm{pH}$, DO, and TSS were instantly measured in the field. Total dissolved solids were determined as the residue left after evaporation of the unfiltered sample.
For COD and BOD measurements, water samples were fixed in the field and brought to the laboratory. Similarly, the Argentometric method for Chloride, Gravimetric method (with the ignition of residue) for Sulfate, Partition gravimetric method for oil and grease, Zincon method for zinc were applied. Total chromium was obtained after digestion of the sample with $\mathrm{H}_{2} \mathrm{SO}_{4}$ and $\mathrm{HNO}_{3}$. To determine total chromium, the trivalent chromium can be oxidized to hexavalent by potassium permanganate. Arsine was identified by passing through a scrubber containing glass wool soaked with lead acetate and absorbed in silver diethyldithiocarbamate dissolved in pyridine. Arsenic reacts with the silver salt to form a red complex, which can be determined colorimetrically. All parameters were measured using the standard guideline given by APHA (1998).

Table 1 Water quality parameters analyzed in the Bagmati River

\begin{tabular}{llll}
\hline \multirow{2}{*}{ Physical Parameters } & \multicolumn{2}{c}{ Chemical Parameters and pesticides } \\
\cline { 2 - 4 } & Organic constituents & Inorganic constituents & Pesticides \\
\hline pH, Total & Dissolved Oxygen & Chloride (Cl), Sulphate (SO) $)$ Fluoride (F), & Organochlorine, Alachlor, Aldrin, \\
(TSS) & (DO), Biological & Sulphide (S), Arsenic (As), Cadmium (Cd), & Dieldrin, Methoxychlor, Endosulfan, \\
& Oxygen Demand & Lead (Pb), Mercury (Hg), Chromium (Cr), & Heptachlor, Heptachlor exoepoxide, \\
& (BOD), Chemical & Oil and grease, Selenium (Se), Zinc (Zn), & Organophosphate, Chlorpyrifos, \\
& Oxygen Demand & Silver (Ag) Copper (Cu), Nickel (Ni), & Chlorfenviphos, Carbamate, Aldicarb, \\
& (COD) & Cyanide (CN) &
\end{tabular}




\section{Results and Discussion}

Physical and chemical parameters

The results showed that the magnitude of water quality parameters, especially TSS, BOD, and COD, vary in different sites. The dissolved oxygen (DO) concentration was found to be higher in the upstream region, declining to a minimum in urban cores and increasing in downstream sites (Fig. 2). The highest DO was found at Sundarijal $(8.5 \mathrm{mg} / \mathrm{L})$, followed by Gokarneshwor $(7.2 \mathrm{mg} / \mathrm{L})$ and Tilganga $(6.3$ $\mathrm{mg} / \mathrm{L}$. The DO level started to decline after Tilganga with the lowest value at Teku (Pachalighat) and Thapathali, accounting for $3.4 \mathrm{mg} / \mathrm{L}$ and $3.5 \mathrm{mg} / \mathrm{L}$, respectively. However, when the river reaches Chobhar, the DO level started to increase by $5.4 \mathrm{mg} / \mathrm{L}$. The DO level at Saibubhanjyang was $5.5 \mathrm{mg} / \mathrm{L}$. The $\mathrm{pH}$ did not vary considerably, ranging between 6.5 and 7.2. The maximum $\mathrm{pH}$ was observed at Thapathali (7.5), whereas the minimum $\mathrm{pH}$ was observed at Gokarneshwor (6.1).

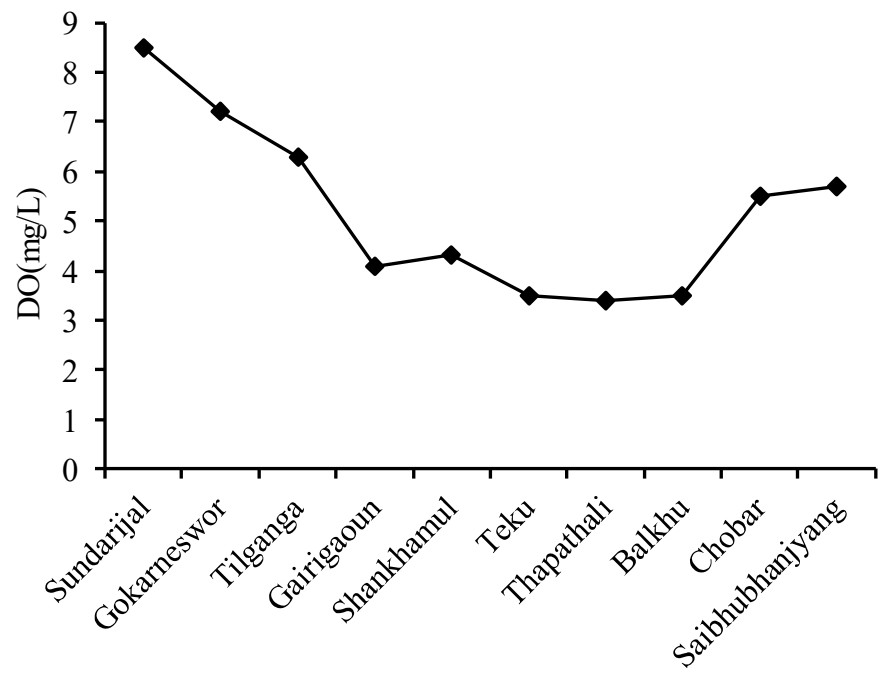

Figure 2 Concentration of dissolved oxygen (DO) at different sampling sites

The physical and chemical parameters are indispensable parameters of water quality assessment to restore the river and ecological balance (Pant et al., 2017; Pradhan, 1998). Quantitative measurements of physico-chemical parameters can describe the quality of the river environment (Mishra et al., 2017; Paudyal et al., 2016). Dissolved oxygen is one of the vital water quality indicators in the river system (Kannel et al., 2007). A suitable pH range (7.0-8.5, WHO standard) is necessary at all times to maintain the health of the aquatic system. The observed $\mathrm{pH}$ ranges between 6.0 and 7.5 across the river stretch from Sundarijal to Saibubhanjyang. The water is a little acidic in the upper region, and the $\mathrm{pH}$ increases gradually towards the downstream region. Land use in the upper segment is mostly agriculture and forest (Uddin et al., 2015). Therefore, agricultural runoff and humus leaching might reduce the $\mathrm{pH}$ level making the water acidic. Towards the city core and downstream sites, $\mathrm{pH}$ gradually increases, which could be due to high ammonia concentration downwards. The presence of high ammonia in water increases the $\mathrm{pH}$ level. The results are compared with the WHO standard for portable water and the national standard for industrial effluent. Similarly, the $\mathrm{pH}$ for the standard of industrial effluent ranges from 5.5 to 9.0 (DOI, 2003), and the drinking water standard is 6.5-8.5 (NDWQS, 2015). The $\mathrm{pH}$ in Bagmati River remained within the given $\mathrm{pH}$ standard.
The maximum concentration of TSS was obtained as 4605 $\mathrm{mg} / \mathrm{L}$ at Thapathali, followed by Teku $(4066 \mathrm{mg} / \mathrm{L})$. The minimum amount of TSS was found at Sundarijal $(2 \mathrm{mg} / \mathrm{L})$ followed by Gokarneshwor $(5 \mathrm{mg} / \mathrm{L})$. The BOD level was lowest $(82 \mathrm{mg} / \mathrm{L})$ at Sundarijal and gradually increased downstream of the river, reaching the highest BOD level at Gairigaun (1885 mg/L). Similarly, Sundarijal accounted for the lowest concentration of COD $(220 \mathrm{mg} / \mathrm{L})$. However, the highest COD (4075 mg/L) was noticed at Gairigaun, followed by Shankhamul (4062 $\mathrm{mg} / \mathrm{L})$. The Chobhar consists of the highest sulphide concentration $(1.7 \mathrm{mg} / \mathrm{L})$, followed by Saibubhanjyang $(1.3 \mathrm{mg} / \mathrm{L})$. Thapathali contained the highest concentration of fluoride and total chlorine with a magnitude of $0.65 \mathrm{mg} / \mathrm{L}$ and $0.5 \mathrm{mg} / \mathrm{L}$, respectively. The lowest amount of sulphide was obtained at Gairigaun (0.35 $\mathrm{mg} / \mathrm{L})$, whereas the lowest fluoride concentration was at Gokarneshwor $(0.05 \mathrm{mg} / \mathrm{L})$, followed by Sundarijal $(0.06 \mathrm{mg} / \mathrm{L})$. Balkhu contained the smallest amount of total chlorine with a magnitude of $0.01 \mathrm{mg} / \mathrm{L}$ (Fig. 3).

The floodplain of the river has been occupied by shantytown and landless people who often use the river as a free dumping site. Therefore, the concentration of ammonia, TSS, and heavy metals like arsenic, cadmium, mercury, nickel, selenium, and copper was increased. The ionic and 
elemental concentrations were found higher in the urbanized and lower region as compared to the headwaters (Paudyal et al., 2016).

The increased TSS concentration after Gokarneshwor is due to increased discharge and volume of waste in the river. The increased inorganic and organic wastes after Gokarneshwor played a crucial role in increasing the TSS. All parameters, including TSS and BOD, declined when water reaches Chobhar and further declines at Saibubhanjyang. The simulation of the previous study also showed that DO and BOD values for 2020 and 2030 would not significantly improve in the Bagmati River (Mishra et al., 2017). The BOD level for the national generic standard for industrial effluent is $50 \mathrm{mg} / \mathrm{L}$, and the WHO standard for portable water is $6 \mathrm{mg} / \mathrm{L}$. These levels exceeded in all sampling sites of Bagmati River. Meanwhile, Gairigaun and Tilganga contained the BOD level 30 times more than the given standard. The less urbanized area such as Sundarijal and Gokarneshwor also exceeded the standard, which clearly showed organic pollution in the river. All sampling sites, except Sundarijal and Gokarneshwor, contained more COD than the WHO standard $(10 \mathrm{mg} / \mathrm{L})$ and standard for the national industrial effluents $(250 \mathrm{mg} / \mathrm{L})$.

The chloride and sulphate concentration is below the maximum allowable concentration for portable water given by WHO, which should not exceed $600 \mathrm{mg} / \mathrm{L}$ and 400 $\mathrm{mg} / \mathrm{L}$, respectively. In the same way, the observed concentration of chloride and sulphate seem below the national standard for industrial effluents $(1000 \mathrm{mg} / \mathrm{L}$ and $500 \mathrm{mg} / \mathrm{L}$, respectively). Except for Sundarijal and Gokarneshwor, the concentration of oil and grease in all sampling sites exceeds both WHO $(1 \mathrm{mg} / \mathrm{L})$ as well as the national generic industrial effluent standard $(10 \mathrm{mg} / \mathrm{L})$. The main cause of high oil and grease is due to a high number of garage and service centers of vehicles along the river corridor. Beside it, the massive inflow of sewage and industrial wastes is the leading cause of oil and grease in the river. Similarly, the WHO standard for ammonia is 0.5 $\mathrm{mg} / \mathrm{L}$, and this value is fulfilled only in Sundarijal and Gokarneshwor. The national effluent standard for ammonia is $50 \mathrm{mg} / \mathrm{L}$, which is also surpassed in all sampling sites except in the upstream region. Sulphide and residual chlorine are not high since the concentration at all sampling sites are below the national standard $(2 \mathrm{mg} / \mathrm{L}$ and $1 \mathrm{mg} / \mathrm{L}$, respectively). The fluoride concentration at all sampling sites is below the WHO $(1.5 \mathrm{mg} / \mathrm{L})$ and national standard (2 $\mathrm{mg} / \mathrm{L})$.

\section{Heavy metals}

The concentration of heavy metals did not vary considerably at different sampling sites (Table 2). The concentration of silver ranges from 0.01 to $0.02 \mathrm{mg} / \mathrm{L}$, which was quite similar at all the sampling sites. Thapathali encountered highest concentration of arsenic $(0.65 \mathrm{mg} / \mathrm{L})$, cadmium $(0.005 \mathrm{mg} / \mathrm{L})$, selenium $(0.007 \mathrm{mg} / \mathrm{L})$ and copper $(0.075$ $\mathrm{mg} / \mathrm{L})$. The mercury concentration was below $0.001 \mathrm{mg} / \mathrm{L}$ in all sampling sites except at Thapathali and Balkhu that accounted for $0.001 \mathrm{mg} / \mathrm{L}$. In the same way, cyanide concentration was below $0.05 \mathrm{mg} / \mathrm{L}$ in Sundarijal, Gokarneshwor, Tilganga, Teku, and Saibubhanjyang, whereas the remaining sites contained a concentration of $0.05 \mathrm{mg} / \mathrm{L}$. The highest zinc concentration was found at Gairigaun (0.85 mg/L), followed by Shankhamul (0.82 $\mathrm{mg} / \mathrm{L}$ ) and Tilganga (0.81 mg/L) (Table 2).

The WHO standard of arsenic for portable water is 0.05 $\mathrm{mg} / \mathrm{L}$, whereas the concentration for the national effluent standard is $0.2 \mathrm{mg} / \mathrm{L}$. Thapathali exceeds these values for arsenic, which is attributed to waste from hospitals and commercial areas. The variation of arsenic was also attributed to a geospatial variation such as latitude, longitude, and depth of tube well or groundwater concentration (Yadav et al., 2014). The human groundwater footprints are more stressful (BGR/UNESCO, 2008; Gleeson et al., 2012), and groundwater are depleting in the Kathmandu valley. The arsenic contamination in food and water has severe effects on human health (Ravenscroft et al., 2009). Other heavy metals, including copper, zinc, lead, cyanide, nickel, selenium, and mercury concentrations also seem below the WHO and national standards.

\section{Pesticides concentration}

Pesticide concentration was found below the measurable range. All sampling sites contained pesticide concentration below $10 \mu \mathrm{g} / \mathrm{L}$, which is connected to less agricultural cultivation and pesticide practices in the Kathmandu valley. The observed data on pesticides was found within a similar range except for Heptachlor exoepoxide. All other compounds from the Organochlorine group were measured below $10 \mu \mathrm{g} / \mathrm{L}$ (Table 3). The highest concentration of Heptachlor exoepoxide was $75 \mu \mathrm{g} / \mathrm{L}$ at Balkhu, followed by Thapathali $(69 \mu \mathrm{g} / \mathrm{L})$ and Teku $(62 \mu \mathrm{g} / \mathrm{L})$. Pesticides from organophosphate, carbamate, and pyrethroids were also measured below the range of $10 \mu \mathrm{g} / \mathrm{L}$ at all sampling sites.

According to the WHO and national effluent standards, the concentration of the pesticides should be zero. However, the concentration of Heptachlor epoxide, an Organochlorine compound, was found to be very high that ranges from 31 to $75 \mu \mathrm{g} / \mathrm{L}$. Other pesticides are also present in the range of below $10 \mu \mathrm{g} / \mathrm{L}$, indicating pesticide pollution in the river. Organochlorines are a synthetic organic product, also known as chlorinated hydrocarbons, which have long term residual effects on the environment and toxic to human health (Yadav \& Devi, 2016).

\section{River pollution and implications for river restoration}

The middle-urbanized segments, i.e., from Gokarna to Teku, have shown heavily polluted. However, the upper segment from Sundarijal to Gokarna is unpolluted (Fig. 4). The concentration of observed pollutants further revealed that the lower segment, i.e., from Teku to Balkhu, gets moderately polluted, and Balkhu to Saibu-Bhanjyang had slightly polluted. Below the Saibu-Bhanjyang, the river gets restored. After the confluences of small tributaries at Shankhamul (Manohara and Hanumante Khola) and Teku (Tukucha, Dhobi Khola, and Bishnumati Khola) have also not filtered Bagmati River because these all tributaries were heavily loaded from urban discharge. The river quality has a little bit of improvement after Balkhu to Saibu-bhanjyang. In between this segment, the Balkhu Khola and Nakkhu Khola are mixed into the Bagmati River. 
Thapathali seems to be the most polluted area since most of the parameters are observed as the highest value. The Bagmati River at Thapathali receives not only household sewage but also waste from hospitals. Two large hospitals (Norvic international and maternity hospitals) are situated in the Thapathali area. Besides, Dhobi Khola, a tributary passing from the city center, confluence the Bagmati River just above the Thapathali site, adding a high amount of waste sludge. Based on these pollutants load in Bagmati River, it can be said that urbanized segments of Bagmati River have shown heavily polluted. After the Saibubhanjyang, the river had got natural restoration.
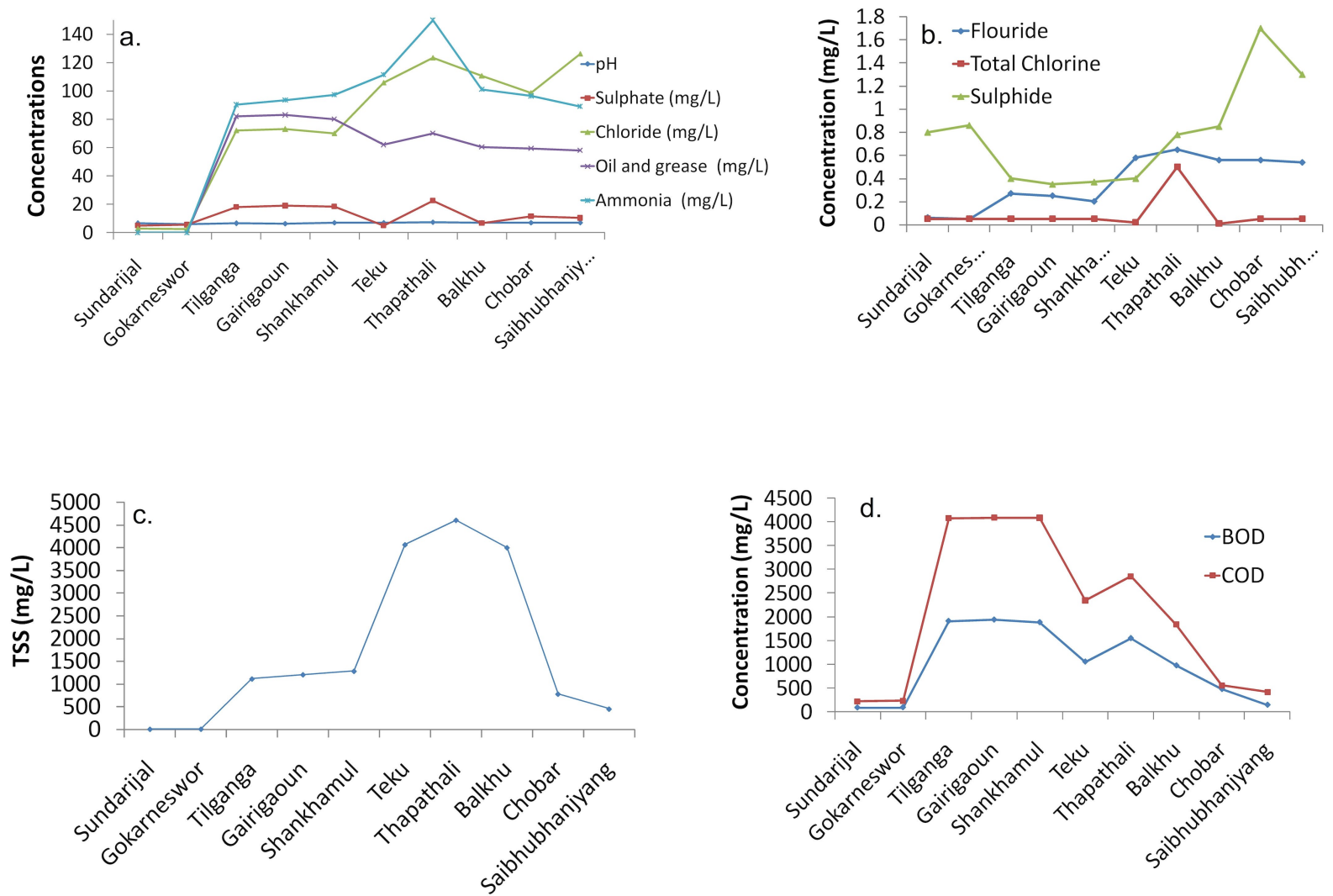

Figure 3 Physical and chemical concentration; a. $\mathrm{pH}$, sulphate, chloride, oil and grease, ammonia; b. fluoride, total chlorine, sulphide; c. total suspended solids and d. BOD and COD (mg/L) at ten sampling sites of the Bagmati River

Table 2 Concentration of heavy metals $(\mathrm{mg} / \mathrm{L})$ at different study sites

\begin{tabular}{lrrrrrrrrrr}
\hline Study sites & \multicolumn{1}{c}{$\mathrm{As}$} & \multicolumn{1}{c}{$\mathrm{Cd}$} & \multicolumn{1}{c}{$\mathrm{Pb}$} & \multicolumn{1}{c}{$\mathrm{Hg}$} & \multicolumn{1}{c}{$\mathrm{Cn}$} & \multicolumn{1}{c}{$\mathrm{Ni}$} & \multicolumn{1}{c}{$\mathrm{Se}$} & \multicolumn{1}{l}{$\mathrm{Cu}$} & $\mathrm{Zn}$ & $\mathrm{Ag}$ \\
\hline Sundarijal & $<0.005$ & $<0.002$ & $<0.05$ & $<0.001$ & $<0.05$ & 0.01 & $<0.005$ & $<0.01$ & 0.07 & 0.01 \\
Gokarneshwor & $<0.005$ & $<0.002$ & $<0.05$ & $<0.001$ & $<0.05$ & 0.01 & $<0.005$ & $<0.01$ & 0.062 & 0.01 \\
Tilganga & $<0.005$ & $<0.002$ & $<0.05$ & $<0.001$ & $<0.05$ & 0.01 & $<0.005$ & 0.16 & 0.81 & 0.01 \\
Gairigaun & $<0.005$ & 0.002 & 0.05 & $<0.001$ & 0.05 & 0.01 & 0.005 & 0.18 & 0.85 & 0.02 \\
Shankhamul & $<0.005$ & 0.002 & 0.05 & $<0.001$ & 0.05 & 0.01 & 0.005 & 0.15 & 0.82 & 0.02 \\
Thapathali & 0.65 & 0.005 & 0.05 & 0.001 & 0.05 & 0.023 & 0.0065 & 0.075 & 0.47 & 0.01 \\
Teku & 0.03 & 0.004 & $<0.05$ & $<0.001$ & $<0.05$ & 0.01 & 0.006 & 0.06 & 0.37 & 0.01 \\
Balkhu & 0.01 & 0.003 & 0.05 & 0.001 & 0.05 & 0.01 & 0.005 & 0.035 & 0.36 & 0.01 \\
Chobhar & $<0.005$ & $<0.002$ & 0.05 & $<0.001$ & 0.05 & 0.01 & $<0.005$ & 0.049 & 0.4 & 0.01 \\
Saibubhanjyang & $<0.005$ & $<0.002$ & $<0.05$ & $<0.001$ & $<0.05$ & $<0.01$ & $<0.005$ & 0.04 & 0.36 & $<0.01$ \\
\hline
\end{tabular}


Currently, the cleaning campaign of the Bagmati River is a concern for all stakeholders and has gathered nationwide attention. The cleaning campaigns by several stakeholders have reached more than 100 weeks. However, it is challenging to improve river quality until the inflow of pollutants is curbed. The urban pollutants are enormous and need to be treated before disposing into the river. So far, several organizations are working to improve the river status.
However, the river condition is not improved. The river restoration plan had envisioned in five years (2009-2014) Bagmati action plans (GoN/NTNC, 2009), which are almost failed; neither river ecosystem has been restored, nor discharge has been increased. Effective ecological restoration measures are required to implement for restoring life on the Bagmati River (Pan et al., 2016).

Table 3 Concentration of pesticides $(\mathrm{mg} / \mathrm{L})$ at various sites

\begin{tabular}{|c|c|c|c|c|c|c|c|c|c|c|}
\hline $\begin{array}{l}\text { Pesticides/study } \\
\text { sites }\end{array}$ & 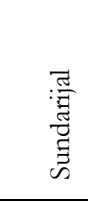 & 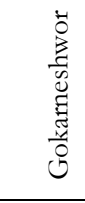 & 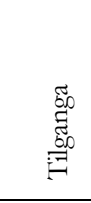 & 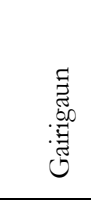 & 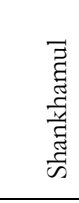 & 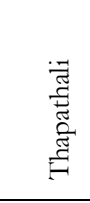 & $\frac{\vec{z}}{0}$ & 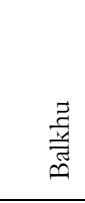 & $\begin{array}{l}\text { चี } \\
\text { - } \\
0 \\
0 \\
0 \\
\text { U }\end{array}$ & 尝 \\
\hline Organochlorine & $<10$ & $<10$ & $<10$ & $<10$ & $<10$ & $<10$ & $<10$ & $<10$ & $<10$ & $<10$ \\
\hline Alachlor & $<10$ & $<10$ & $<10$ & $<10$ & $<10$ & $<10$ & $<10$ & $<10$ & $<10$ & $<10$ \\
\hline Aldrin & $<10$ & $<10$ & $<10$ & $<10$ & $<10$ & $<10$ & $<10$ & $<10$ & $<10$ & $<10$ \\
\hline Dieldrin & $<10$ & $<10$ & $<10$ & $<10$ & $<10$ & $<10$ & $<10$ & $<10$ & $<10$ & $<10$ \\
\hline Methoxychlor & $<10$ & $<10$ & $<10$ & $<10$ & $<10$ & $<10$ & $<10$ & $<10$ & $<10$ & $<10$ \\
\hline Endosulfan & $<10$ & $<10$ & $<10$ & $<10$ & $<10$ & $<10$ & $<10$ & $<10$ & $<10$ & $<10$ \\
\hline $\begin{array}{l}\text { Heptachlor } \\
\text { Heptachlor }\end{array}$ & $<10$ & $<10$ & $<10$ & $<10$ & $<10$ & $<10$ & $<10$ & $<10$ & $<10$ & $<10$ \\
\hline exoepoxide & 40 & 40 & 45 & 50 & 58 & 69 & 62 & 75 & 36 & 31 \\
\hline Organophosphate & $<10$ & $<10$ & $<10$ & $<10$ & $<10$ & $<10$ & $<10$ & $<10$ & $<10$ & $<10$ \\
\hline Chlorpyrifos & $<10$ & $<10$ & $<10$ & $<10$ & $<10$ & $<10$ & $<10$ & $<10$ & $<10$ & $<10$ \\
\hline Chlorfenviphos & $<10$ & $<10$ & $<10$ & $<10$ & $<10$ & $<10$ & $<10$ & $<10$ & $<10$ & $<10$ \\
\hline Carbamate & $<10$ & $<10$ & $<10$ & $<10$ & $<10$ & $<10$ & $<10$ & $<10$ & $<10$ & $<10$ \\
\hline Aldicarb & $<10$ & $<10$ & $<10$ & $<10$ & $<10$ & $<10$ & $<10$ & $<10$ & $<10$ & $<10$ \\
\hline Cabofuran & $<10$ & $<10$ & $<10$ & $<10$ & $<10$ & $<10$ & $<10$ & $<10$ & $<10$ & $<10$ \\
\hline Pyrithoids & $<10$ & $<10$ & $<10$ & $<10$ & $<10$ & $<10$ & $<10$ & $<10$ & $<10$ & $<10$ \\
\hline Deltamethrin & $<10$ & $<10$ & $<10$ & $<10$ & $<10$ & $<10$ & $<10$ & $<10$ & $<10$ & $<10$ \\
\hline Cypermethrin & $<10$ & $<10$ & $<10$ & $<10$ & $<10$ & $<10$ & $<10$ & $<10$ & $<10$ & $<10$ \\
\hline
\end{tabular}

River restoration is one of the prominent areas of applied water resources science (Wohl et al., 2015), and it is possible to make river water pristine and biologically alive. One of the examples of the Qinhuai River of Nanjing, China, can be taken as a successful example of river restoration (NORRP, 2008). This study provides a fundamental assessment of the pollution load in the Bagmati River, which is primarily essential for ecological restoration along with the river segments in the Kathmandu Valley.

\section{Conclusion}

In this study, we have investigated a total of thirty physical and chemical parameters and compared with national and WHO quality standard. The water in the upstream region, covering Sundarijal to Gokarneshwor sites are comparatively cleaner since most of the parameters are within the WHO and national effluent standard. Thapathali is the most polluted area, which exceeds the carcinogenic compound such as arsenic. Most of the parameters exceed both the WHO and national generic effluent standards. The pollution level started to decrease when the river reached to Chobhar site. However, some parameters such as BOD, COD, oil, and grease have exceeded both WHO and national standards. No considerable variation has been found in the concentration of heavy metals, pesticides, and $\mathrm{pH}$ in the upstream and downstream regions. However, the difference in TSS, BOD, and COD was observed, which was attributed to increased flow rate and temperature. It has indicated that the urbanized segment of the Bagmati River had been heavily polluted. It reflects an urgent need for ecological restoration using a large variety of ecological, physical, spatial management measures and practices. In Bagmati River, sludge treatment is essential before disposing into the river. At the same time, all tributaries of the river should be treated equally. 


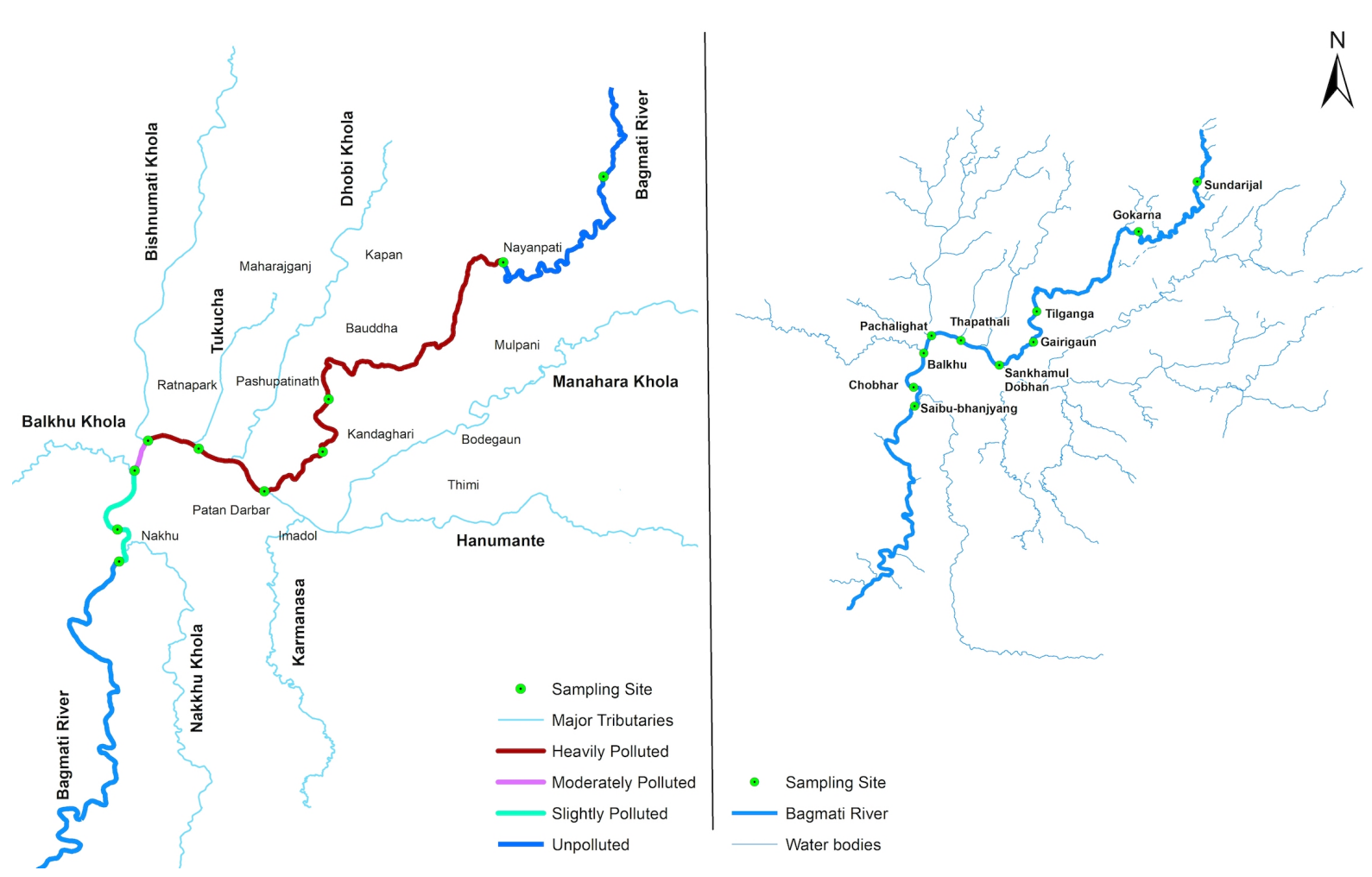

Figure 4 Major tributaries and degree of pollution level in Bagmati River from Sundarijal to Saibu Bhanjyang segments in the Kathmandu valley; the right map shows the drainage and sampling sites of the study area

\section{Acknowledgements}

Nitesh Khadka is supported by the CAS-TWAS President's fellowship. The Department of Environment, Ministry of Environment and Forest, Government of Nepal supported this research project. We thank the Department for its financial support. We also thank Nepal Environment and Scientific Services (NESS), (P). Ltd and Water Engineering and Training Center (P) Ltd. for their laboratory support.

\section{References}

ADB. (2013). ADB to belp Nepal restore bealth of stressed Bagmati River basin. Asian Development Bank, Kathmandu, Nepal

APHA. (1998). Standard methods for the examination of water and wastewater. 20th edition, American Public Health Association (APHA), Washington DC.

Baniya, B., Techato, K.-A., Ghimire, S.K., \& ChhipiShrestha, G. (2018). A review of green roofs to mitigate urban heat island and Kathmandu valley in Nepal. Applied Ecology and Environmental Sciences, 6, 137-152. doi 10.12691/aees-6-4-5.

BGR/UNESCO. (2008). Ground water resources map of the world (scale 1:25000000, (https;//www.whymap.org/whymap/EN/Products_no de_en.html).

Bhatt, M.P., \& Gardner, K.H. (2009). Variation in DOC and trace metal concentration along the heavily urbanized
We are grateful to Horticulture Enterprise and Research Center (HERC) for institutional supports. We also express our thankfulness to the Department of Environmental Science, Patan Multiple Campus, Tribhuvan University, Nepal. The authors would like to thank the editor and three anonymous reviewers for their insightful comments and suggestions, which helped improve the manuscript.

basin in Kathmandu valley, Nepal. Environmental Geology, 58, 867-876. doi 10.1007/s00254-008-1562-z.

Bhatt, M.P., McDowell, W., Gardner, K.H., \& Hartmann, J. (2013). Chemistry of the heavily urbanized Bagmati River system in Kathmandu valley, Nepal: export of organic matter, nutrients, major ions, silica, and metals. Environmental Earth Sciences, 71, 911-922. doi 10.1007/s12665-013-2494-9.

CBS. (2011). Population monograph of Nepal. National Planning Commission Secretariat, Central Bureau of Statistics (CBS), Government of Nepal.

Chapman, D. (1992). Water quality assessment. London: Chapman and Hall (on behalf of UNESCO, WHO and UNEP).

Dahal, A., Khanal, M., \& Ale, M. (2011). Bagmati River festival: conservation of degrading river. Proceeding of 
the 2011 Georgia Water Resource Conference, University of Georgia.

Dhital, Y.P., Tang, Q., \& Shi, J. (2013). Hydroclimatological changes in the Bagmati River basin, Nepal. Journal of Geographical Sciences, 23, 612-626. doi:10.1007/s11442013-1032-8.

DHM. (1996). Water quality data of rivers in Kathmandu valley, 1992-1995. Department of Hydrology and Meteorology (DHM), Nepal.

DHM. (2008). Water quality summary, 1992-2006. Department of Hydrology and Meteorology (DHM), Nepal.

DOI. (2003). Ground water project, Nepal Gazette, 2001 and 2003, Department of Irrigation (DOI), Nepal.

ENPHO. (1997). Monitoring and assessment of water quality in the Shivapuri watershed. Environment and Public Health Organization (ENPHO), HMG/FAO, Kathmandu, pp $1-114$.

Gleeson, T., Wada, Y., Bierkens, M.F.P., \& Beek, L.P.H. (2012). Water balance of global aquifers revealed by groundwater footprint. Nature, 488, 197-200. doi 10.1038 / nature 11295 .

GoN/NTNC. (2009). Bagmati Action Plan (2009-2014). Kathmandu, Nepal.

ICIMOD. (2007). Kathmandu valley environment outlook. Internationl Center for Integrated Mountain Development (ICIMOD), Ministry of Forest and Environment (MoFE) and United Nations Environment Program (UNEP).

ITECO. (2003). Feasibility study and detail engineering design to update master plan for Bagmati area sewage project. Final Report, Government of Nepal, p. 1-69.

Kannel, P.R., Lee, S., Lee, Y.S., Kanel, S., \& Khan, S.P. (2007). Application of water quality indices and dissolved oxygen as indicators for river water classification and urban impact assessment. Environmental Monitoring and Assessment, 132, 93-110. doi 10.1007/s10661-006-9505-1.

Karna, S.K., \& Harada, H. (2001). Surface water pollution in three urban territories of Nepal, India and Bangladesh. Environment Management, 28, 483-496. doi $10.1007 / \mathrm{s} 002670010238$.

Mishra, B.K., Regmi, R.K., Masago, Y., Fukushi, K., Kumar, P., \& Saraswat, C. (2017). Assessment of Bagmati River pollution in Kathmandu valley: Scenario-based modeling and analysis for sustainable urban development. Sustainability of W ater Quality and Ecology, 910, 67-77. doi 10.1016/j.swaqe.2017.06.001.

MoLD. (2011). Annual report. Ministry of Local Development, Government of Nepal, Singh durbar, Kathmandu.

MoUD. (2013). Kathmandu valley drinking water status and improvement project. Ministry of Urban Development (MoUD), Singh durbar, Kathmandu, Nepal.

MoUD. (2015). Annual Report. Ministry of Urban Development (MoUD), Government of Nepal (GoN), Singhdurbar, Kathmandu, Nepal.

NDWQS. (2015). Implementation directives for National Water Quality Standard (NWQS). Department of Water Supply and Sewerage (DWSS), World Health Organization (WHO), Kathmandu, Nepal.

NORRP. (2008). Briefing of Nanjing Qinbuai River Rebabilitation Project. Government of China.
NUDS. (2015). National Urban Development Strategy (NUDS). Government of Nepal, Ministry of Urban Development (MoUD), Singhdurbar, Kathmandu.

NWCF/NTNC. (2009). The Bagmati: issues, challenges and prospects. National Water Conservation Foundation and National Trust for Nature Conservation (NTNC), Nepal.

Pan, B., Yuan, J., Zhang, X., Wang, Z., Lu, J., Yang, W., Chen, J., Li, Z., Zhao, N., \& Xu, M., (2016). A review of ecological restoration techniques in fluvial rivers. International Journal of Sediment Research, 31(2), 110-119. doi 10.1016/j.ijsrc.2016.03.001.

Pant, R.R., Zhang, F., Rehman, F.U., Wang, G., Ye, M., Zeng, C., \& Tang, H. (2017). Spatiotemporal variations of hydrogeochemistry and its controlling factors in the Gandaki River basin, Central Himalaya Nepal. Science of the Total Environment, 622-623, 770-782. doi 10.1016/j.scitotenv.2017.12.063.

Paudel, A. (1998). Bagmati River water quality management: problems and constraints. Department of Water Supply and Sewerage (DWSS), Society of Public Health Engineers Nepal (SPHEN), UNICEF and WHO in Kathmandu, Nepal.

Paudyal, R., Kang, S., Sharma, C.M., Tripathee, L., \& Sillanpää, M. (2016). Variations of the physicochemical parameters and metal levels and their risk assessment in urbanized Bagmati River, Kathmandu, Nepal. Journal of Chemistry, 6025905. doi 10.1155/2016/6025905.

Pradhan, B. (1998). Water quality assessment of the Bagmati River and its tributaries, Kathmandu valley, Nepal. Institute of Water Provision, Water Ecology and Waste Management, BOKU University, Vienna, Austria.

Ravenscroft, P., Brammer, H., \& Richards, K. (2009). Arsenic pollution: A global synthesis. Wiley-Blackwell.

Shrestha, B., Ye, Q., \& Khadka, N. (2019). Assessment of ecosystem services value based on land use and land cover changes in the transboundary Karnali River basin, central Himalayas; Sustainability, 1(11), 3183. doi $10.3390 /$ su11113183.

Shrestha, P., Pradhan, B., Shah, D.N., Techamo, R.D., Sharma, S., \& Moog, O. (2008). Water quality mapping of the Bagmati River basin, Kathmandu valley. In O. Moog, D. Hering, S. Sharma, I. Stubauer, \& T. Korte, (Eds.) Proceedings of the Scientific Conference: River in the Hindukush Himalaya-Ecology and Environmental Assessment (pp. 189-197). University of Natural Resources and Applied Life Sciences, Vienna.

Shrestha, P., \& Tamrakar, N. (2012). Morphology and classification of the main stem Bagmati River, Central, Nepal. Bulletin of the Department of Geology, 15, 23-24.

STANLEY. (1994). Bagmati basin water management strategy and investment program. Final report, Government of Nepal, Ministry of Housing and Physical Planning (MHPP)/JICA/World Bank.

Uddin, K., Shrestha, H.L., Murthy, M.S.R., Bajracharya, B., Shrestha, B., \& Gilani, H. (2015). Development of 2010 national land cover database for Nepal. Journal of Environmental Management, 148, 82-90. doi 10.1016/j.jenvman.2014.07.047.

Udmale, P., Ishidaira, H., Thapa, B.R., \& Shakya, N.M. (2016). The status of domestic water demand: supply 
deficit in the Kathmandu valley, Nepal. Water, 8, 196. doi 10.3390/w8050196.

WECS. (2011). Water resources of Nepal in context of climate changes. Water and Energy Commission Secretariat (WECS), Government of Nepal, Singhdurbar, Kathmandu, pp.67.

WHO. (2008). Guidelines for drinking water quality: volume 1, Chapter 9- standards of potable water quality and waterborne disease, World Health Organization (WHO).

Wohl, E., Lane, S., \& Wilcox, A.C. (2015). The science and practice of river restoration. Water Resources Research, 51(8), 5974-5997. doi 10.1002/2014WRO16874.
Yadav, I.C., \& Devi, N.L. (2016). Pesticides classification and its impact on human and environment. In A. Kumar, J.C. Singhal, K. Techato, L.T. Molina, N. Singh, P. Kumar, P. Kumar, R. Chandra, S. Caprio, S. Upadhye, S. Yonemura, S.Y. Rao, T.C. Zhang, U.C. Sharma, \& Y.P. Abrol (Eds.), Environment science and engineering. Stadium Press LLC, USA, pp. 149-156.

Yadav, I.C., Devi, N.L., \& Singh, S. (2014). Spatial and temporal variation of arsenic in the groundwater of upstream of Ganges River basin, Nepal. Environmental Earth Sciences, 73, 1265-1279. doi 10.1007/s12665-0143480-6. 